\title{
ETIKA BISNIS DALAM PERSPEKTIF ISLAM
}

\author{
Abd. ghafur ${ }^{1}$
}

\begin{abstract}
In 1997-1998 Indonesia experienced a monetary crisis and economic crisis, where one of the factors causing it is the existence of economic wideenization. The image arises because the business ethics of entrepreneurs in Indonesia is low. If analyzed more deeply, the phenomenon is called the term "seller's market", which means the market is dominated by the seller, where the powerful seller is doing a lot of monopoly activities by ignoring the business ethics that becomes an important spirit in business activities.

To build a healthy culture in business then it is necessary to use Islamic business ethics that there is a principle about the Barometer of Person and Person Ketaqwaan is a means for worship to Allah SWT. But to start Islamic business ethics must do several things: (1) Intention Ikhlas Expect Ridha Allah SWT. (2) Professional (3) Honest \& Trustful (4) Promoting Ethics of a Muslim (5) Not Breaking Sharia Principles (6) And the last is Ukhuwah Islamiyah.
\end{abstract}

Keywords: Ethics, Business, Islam

\footnotetext{
${ }^{1}$ Dosen Tetap Fakultas Ekonomi dan Bisnis Islam INZAH GENGGONG KRAKSAAN
} 


\section{A. Pendahuluan}

Bisnis tidak dapat dipisahkan dengan kehidupan manusia, bahkan bisnis merupakan salah satu kegiatan yang populer dalam kehidupan sehari-hari manusia. Setiap hari manusia melakukan kegiatan bisnis. Manusia berperan sebagai produsen, perantara, maupun konsumen. Produsen menghasilkan produk dalam kegiatan bisnis, dimana produk tersebut akan menghasilkan keuntungan dan nilai tambah bagi konsumen. Seiring dengan perkembangan zaman, maka dewasa ini bisnis semakin kompleks. Seorang pebisnis tidak hanya dituntut untuk memiliki keberanian dalam mengambil tindakan bisnis, namun juga pengetahuan dan wawasan yang mendukung, sehingga keputusan bisnis yang diambil bisa diminimalkan risikonya, dan dioptimalkan keuntungannya. ${ }^{2}$

Pada tahun 1997-1998 Indonesi mengalami krisis moneter dan krisis ekonomi, di mana salah satu faktor penyebabnya adalah adanya lebaralisasi ekonomi. Pada saat itu, banyak bank yang berdiri bebas dengan hanya menggunakan mudal 10 miliyar saja. Saat itu diberikan berbagai kelonggaran untuk meminjam utang yang sebesarbesarnya, tampa pengawasan dan seleksi ketat dari pemerintah. Selain itu, pemerintahpun melakukan hal yang serupa, meminjam dana dari luar Negeri dengan dalih pembangunan ekonomi. Dan yang dipinjam yang sifatnya dalam jangka pendek di investasikan untuk bisnis jangka panjang, sehingga terjadi salah pengelolaan dana investasi. Akibatnya pada saat utang jatuh tempo, banyak pengusaha yang tidak mampu membayar utang secara tepat waktu.

Kondisi tersebut menyebabkan reputasi Indonesia menjadi jatuh di dunia Internasional. Indonesia termasuk kepada Negara yang yang memiliki contry risk tinggi. Citra tersebut muncul karena etika bisnis pengusaha yang ada di Indonesia rendah, di mana meraka lebih berlomba-lomba untuk membangun berbagai gedung bertingkat, sehingga dana yang seharusnya di gunakan untuk kegiatan produktif nyatanya digunakann untuk kegiatan yang konsumtif.

Jika dianalisis lebih mendalam, fenomena tersebut di sebut dengat istilah "seller's market", yang artinya pasar dikuasai oleh penjual, dimana penjual yang berkuasa banyak melakukan kegiatan monopoli dengan mengabaikan etika bisnis yang menjadi ruh penting dalam kegiatan bisnis. ${ }^{3}$

Sistem etika bisnis Islam berbeda dengan sistem etika sekuler. Sistem sekuler mengasumsikan sejumlah kode moralitas yang sangat entropis, karena konsep moral dari sistem etika tersebut berdiri diatas nilai-nilai temuan manusia. Sistem etika tersebut mengusulkan sebuah sistem penceraian antara etika dan agama.

Lain halnya dengan sistem etika bisnis Islam, nilai moralitas etika Islam menanamkan anjuran akan hubungan manusia dengan Tuhannya. Sistem etika Islam

\footnotetext{
Hlm. 110

${ }^{3}$ Buchari Alwa \& Doni Juni Priansa, Manejemen Bisnis Syariah. Hlm. 372-374
}

${ }^{2}$ Buchari Alwa \& Doni Juni Priansa, Manejemen Bisnis Syariah (Bandung: Alfabeta, 2016), 
bisa ditekankan kapan saja, tidak terikat dengan satu masa tertentu, karena Allah sebagai sang pencipta dan para pencatatnya sangat dekat dengan manusia sebagai hamba. Bagi seorang muslim, kemampuan pradigma konvensional akan arti manusia sebagai "homo economicus" (pelaku ekonomi yang mencari keuntungan bagi dirinya tampa mengindahkan kepentingan orang lain) tidak sepenuhnya sesuai dengan nilainilai Etika Bisnis Islam. Oleh sebab itu, morality concept dalam perspektif Islam diusung pada saat pencerahan aksioma-aksioma yang sudah terlanjur kondang (dari sistem kapitalis), apresiasi manusia umum akan materi (property of wealth) pelanpelan harus digeser malalui arahan rambu-rambu imperatif syariah. Karena muatan 'tercerah' dan perspektif ini adalah dimensi moral berbasis wahyu. Dengan demikian, sudah selayaknya commercial ethis dapat menjadi salah satu kajian yang harus melenglapi Islamization process infrastruktur sistem kehidupan sosial dan ekonomi penganut agama ${ }^{4}$.

\section{B. Pembahasan}

1. Definisi Etika Bisnis Islam

Secara sederhana mempelajari etika dalam bisnis berarti mempejari tentang mana yang baik/buruk, benar/salah dalam dunia bisnis berdasarkan kepada prinsip moralitas. Kajian etika bisnis terkadang merujuk kepada menegemen ethis atau organizational ethis. Etika bisnis dapat berarti pemikiran atau refleksi tentang moralitas dalam ekonomi dan bisnis.

Moralitas di sisni, sebagaimana disinggung di atas berarti: aspek baik/buruk, terpuji/tercela, benar/salah, wajar/tidak wajar, pantas/tidak pantas dari perilaku manusia. Kemudian dalam kajian etika bisnis Islam ditambah dengan halal-haram. ${ }^{5}$

2. Etika Bisnis Konvensional Versus Islam

Dalam kaitannya dengan pradigma Islam tentang bisnis, maka landasan filosufis yang harus dibangun dalam pribadi Muslim adanya konsepsi hubungan manusia dengan Tuhan-Nya. Yang dalam bahasa agama di kenal dengan istilah (hablum minullah wa hablum minannas).

Dalam ekonomi Islam, bisnis dan etika tidak harus dipandang sebagai dua hal yang bertentangan, sebab, bisnis yang merupakan simbol dari urusan duniawi juga dianggap sebagai integral dari hal-hal yang bersifat investasi akhirat. Artinya, jika orientasi bisnis dan upaya investasi akhirat (diniatkan sebagai ibadah dan merupakan totalitas kepatuhan kepada Tuhan), maka bisnis dengan sendirinya harus sejalan dengan kaidah-kiadah moral yang berlandasan keimanan kepada akhirat. Bahkan dalam Islam, pengetian bisnis tidak di batasi

\footnotetext{
${ }^{4}$ Faisal Badroen, et al, Etika Bisnis Dalam Islam (Jakarta: Prenadamedia Group, 2012), Hlm. $68-70$

${ }^{5}$ Faisal Badroen, et al, Etika Bisnis Dalam Islam. hal. 70
} 
dengan urusan dunia saja, tetapi mencakup seluruh kegiatan di dunia yang "dibisniskan" (diniatkan sebagai ibadah) untuk meraih keuntungan atau pahala akhirat.

Dalam konsep Islam, sebenarnya Allah telah menjamin bahwa orang yang bekerja keras mencari jatah duniawinya dengan tetap mengindahkan kaidah-kaidah akhirat untuk memperoleh kemenangan duniawi, maka ia tercatat sebagai hamba Tuhan dengan memiliki keseimbangan tinggi. Sebagaimana sabda Nabi:

"Barang siapa yang menginginkan dunia, maka hendaknya dia berilmu, dan barang siapa yang menginginkan akhirat maka hendaknya dia berilmu, dan barang siapa menghendaki keduanya maka hendaknya dia berilmu."

Pernyataan Nabi tersebut mengisyaratkan dan mengonfirmasikan bahwa disamping persoalan etika yang menjadi tumpuan kesuksesan dalam bisnis juga ada faktor lain, yaitu, skiil dan pengetahuan tentang etika itu sendiri. Gagal mengetahui pengetatahuan tentang etika maupun prosedur bisnis yang benar secara Islam maka akan gagal memperoleh tujuan. Jika Ilmu yang dibangun untuk mendapatkan kebahagiaan akhirat juga bebasis etika, maka dengan sendirnya ilmu yang dibangun untuk duniapun harus bebasis etika.

Dari sudut pandang dunia bisnis kasus Jepang setidaknya telah membuktikan keyakinan, bahwa motivasi perilaku ekonomi yang memiliki tujuan lebih besar dan lebih tinggi (kesetiaan pada norma dan nilai etika baik) ketimbang bisnis semata, ternyata telah mampu mengungguli pencapaian ekonomi Barat (seperti Amerika) yang hampir semata-mata didasarkan pada kepentingan diri dan materialism serta menafikan aspek spiritualisme.

Dapat disimpulkan bahwa dalam kehidupan ini setiap manusia sering kali mengalami ketegangan atau delema etis antara harus memilih keputusan etis dan keputusan bisnis sempit semata sesuai dengan lingkungan dan peran tanggung jawabnya, tetapi jika percaya pada sabda Nabi Muhamammad SAW. atau logika ekonomi diatas, maka jika melilih keputusan etis maka pada hakikatnya juga sedang meraih bisnis. ${ }^{6}$

3. Konsep al-Qur'an tentang Bisnis

Sebagaimana di ketahui bahwa al-Qur'an adalah sumber nilai sumber dari segala sumber untuk pegangan hidup umat Islam. Maka terkait itu, alQur'an telah membicarakan bisnis, sekaligus merupakan bukti bahwa Islam memberikan perhatian terhadap bisnis sebagai prata sosial. Bahkan al-Qur'an

\footnotetext{
${ }^{6}$ Abdul Aziz, Etika Bisnis Perspekitif Islan : Implementasi Etika Islam untuk Dunia Usaha
} (Bandung: AL-Fabeta, 2013), Hlm.97-100 
juga memotivasi usaha komersial dan perdagangan dengan cara memberikan keberanian atau semangat untuk berwiraswasta. ${ }^{7}$

Bisnis dalam al-Qur'an dijelaskan melalui kata tijarah, yang mencakup dua makna, yaitu: pertama, perniagaan secara umum yang mencakup perniagaan antara manusia dengan Allah. Ketika seseorang memilih petunjuk dari Allah, mencintai Allah dan Rasul-Nya, berjuang di jalan-Nya dengan harta dan jiwa, membaca kitab Allah, mendirikan sholat, menafkahkan sebagian rezekinya, maka itu adalah sebaik-baiknya perniagaan antara manusia dengan Allah. Dalam salah satu ayat al-Qur'an dijelaskan bahwa ketika seseorang membeli petunjuk Allah dengan keesaan, maka ia termasuk seseorang yang beruntung.

Adapun makna kata tijarah yang kedua adalah perniagaan secara khusus, yang berarti perdagangan atau jual beli antara manusia. Beberapa ayat yang menerangkan tentang bagaimana bertransaksi yang adil di antara manusia terangkum dalam Q.S. al-Baqarah [2]: 282; an-Nisa'[4]: 29; dan anNur[24]: 37. Pada ayat al-Baqarah disebutkan tentang etika dan tata cara jual beli, utang piutang, sewa-menyewa, dan transaksi lainnya. Ayat ini pula dapat dijadikan pedoman kegiatan akuntansi (kewajiban untuk mencatat transaksi) dan notariat (kewajiban adanya persaksian dalam transaksi) dalam pembahasan dalam ekonomi dan bisnis Islam. Sehingga diharapkan adanya suatu perniagaan yang adil dan saling menguntungkan antara satu pihak dengan pihak yang lainnya. Dan motif dari suatu perniagaan hendaknya untuk beribadah, karena dalam Q.S. an-Nur disebutkan bahwa seseorang ketika sedang bertransaksi hendaklah selalu mengingat kepada Alllah, menegakkan shalat dan membayar zakat. Perniagaan dalam arti khusus pun tidak akan lepas dari aktiftas untuk mengingat Allah. Sehingga diharapkan hal ini bisa menjadi kontrol bagi seorang peniaga dan pengusaha, agar selalu berbuat kebaikan dan menjauhi perilaku yang merugikan dalam suatu aktifitas bisnis.

a. Ayat-ayat yang berkaitan dengan Bisnis (Tijarah) secara umum

Tijarah dalam artian suatu perniagaan yang umum, terdapat dalam beberapa ayat al-Qur'an, yaitu:

1) Q.S al-Baqarah [2]: 16:

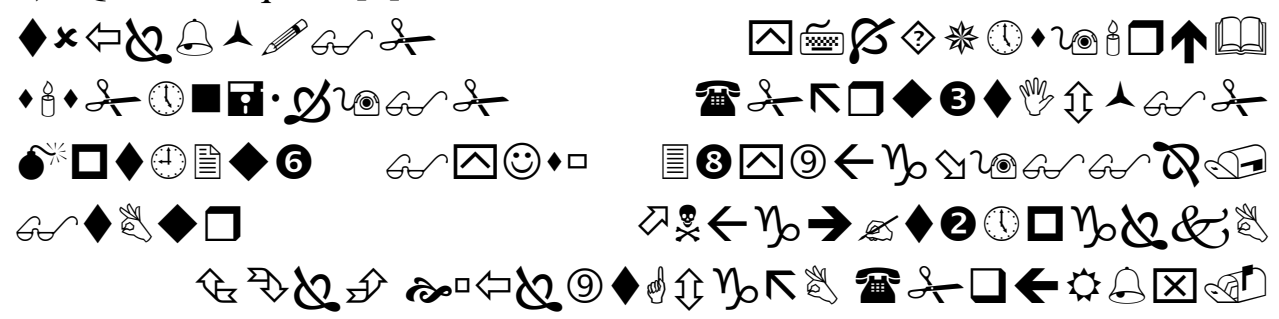

\footnotetext{
${ }^{7}$ Abdul Aziz, Etika Bisnis Perspekitif Islan : Implementasi Etika Islam untuk Dunia Usaha.
} HIm. 101 
mereka Itulah orang yang membeli kesesatan dengan petunjuk, Maka tidaklah beruntung perniagaan mereka dan tidaklah mereka mendapat petunjuk. (Q.S al-Baqarah [2]: 16)

2) Q.S. at-Taubah [9]: 24:

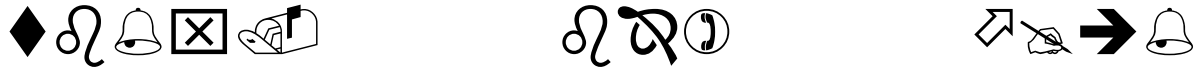

$$
\begin{aligned}
& \text { 邓是 }
\end{aligned}
$$

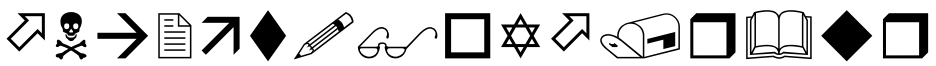

$$
\begin{aligned}
& \text { 邓 } \\
& \text { «बत }
\end{aligned}
$$

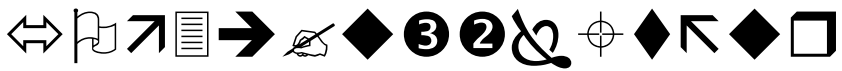

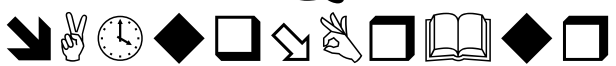

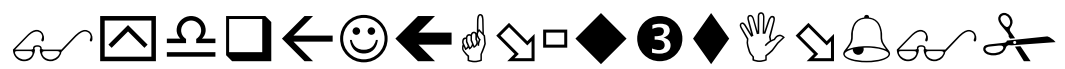

$$
\begin{aligned}
& \checkmark \Omega \text { ऽ } \\
& \text { G } \triangle \Omega \Omega(10 \text { or } \mathrm{O} \text { Х } \\
& \leftarrow \text { II }
\end{aligned}
$$

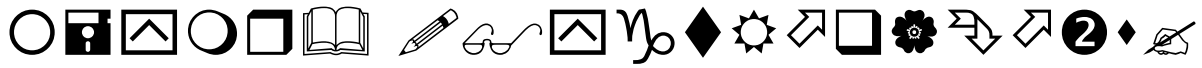

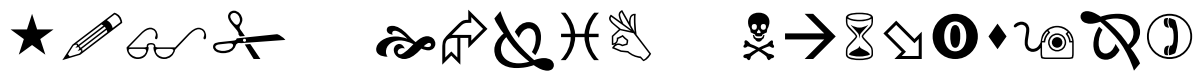

$8 \nabla \times$

(1) Q $\mathbb{E}$ Q Q

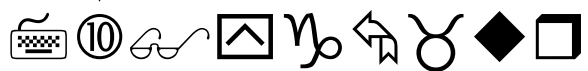

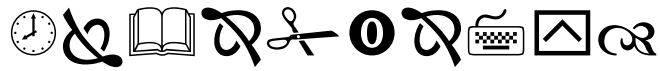

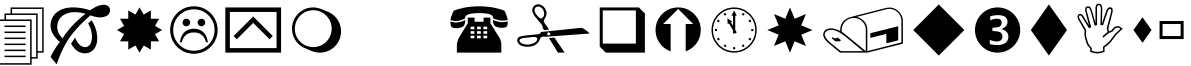

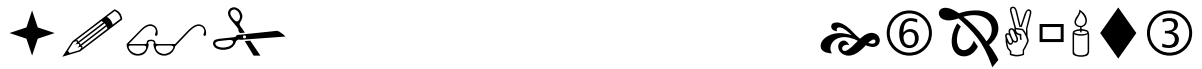

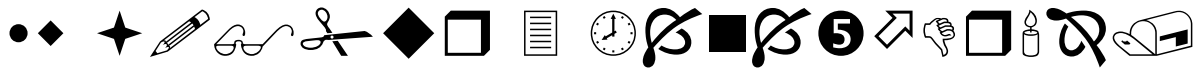

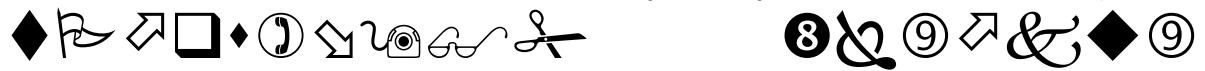

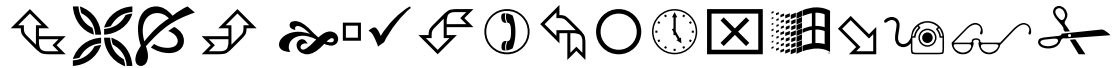
Katakanlah: "Jika bapa-bapa, anak-anak, saudara-saudara, isteriisteri, kaum keluargamu, harta kekayaan yang kamu usahakan, perniagaan yang kamu khawatiri kerugiannya, dan tempat tinggal yang kamu sukai, adalah lebih kamu cintai dari Allah dan RasulNya dan dari berjihad di jalan nya, Maka tunggulah sampai Allah mendatangkan keputusan NYA". dan Allah tidak memberi petunjuk kepada orang-orang yang fasik.(Q.S at-Taubah [9]: 24)

3) Q.S. al-Fatit [35]: 29: 
$\checkmark x \diamond d \theta<$ ar \&

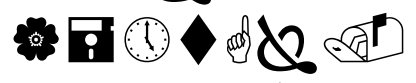

$\square \delta$ व(ग

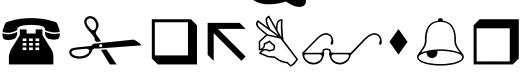

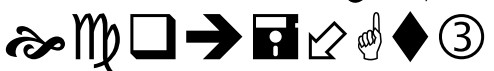

$\star$ Gor

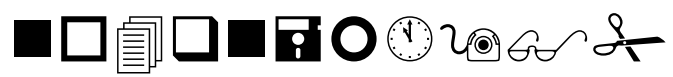

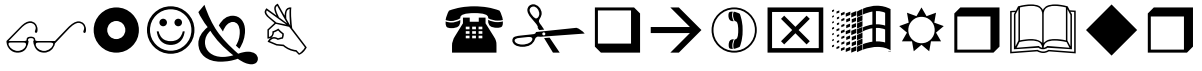

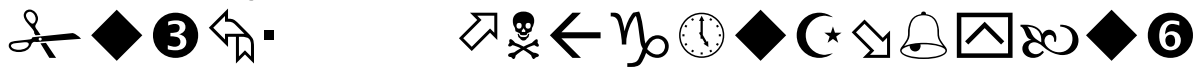

2m

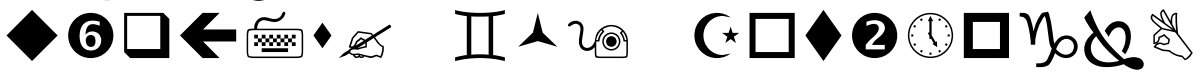

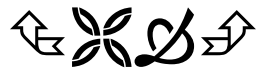

Sesungguhnya orang-orang yang selalu membaca kitab Allah dan mendirikan shalat dan menafkahkan sebahagian dari rezki yang Kami anuge- rahkan kepada mereka dengan diam-diam dan terangterangan, mereka itu mengharapkan perniagaan yang tidak akan merugi. (Q.S al-Fatir [35]: 29)

4) Q.S al-Shaf [61]: 10 dan 11

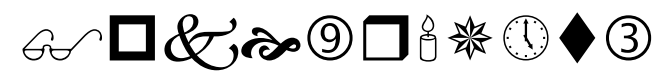

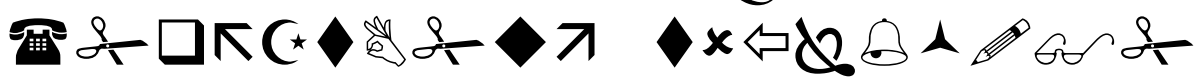

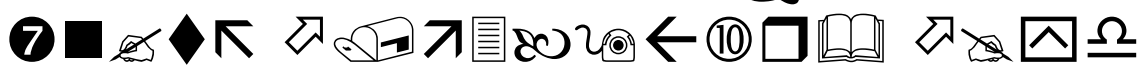

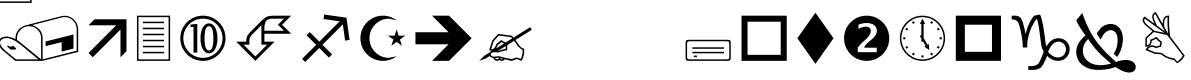

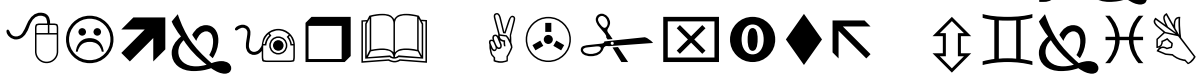

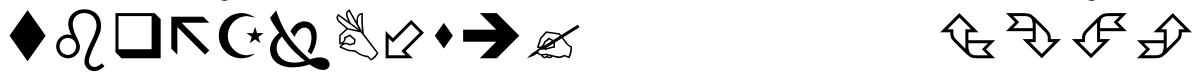

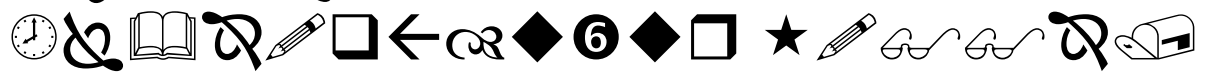

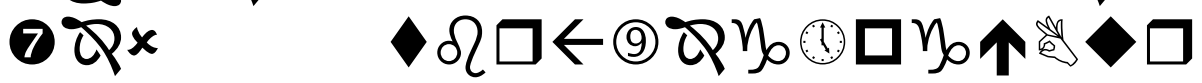
* of \&

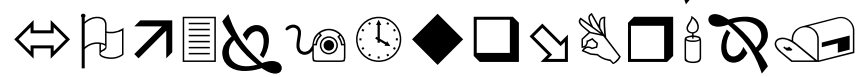

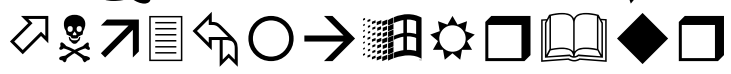

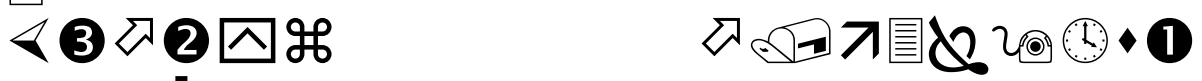

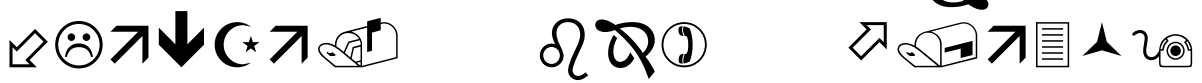

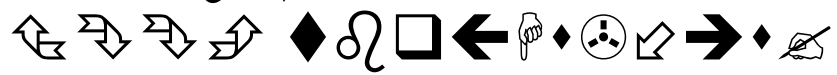

Hai orang-orang yang beriman, sukakah kamu aku tunjukkan suatu perniagaan yang dapat menyelamatkanmu dari azab yang pedih?

(yaitu) kamu beriman kepada Allah dan RasulNya dan berjihad di jalan Allah dengan harta dan jiwamu. Itulah yang lebih baik bagimu, jika kamu mengetahui. (Q.S al-Shaf [61]: 10 dan 11) 
5) Q.S. al-Jumu'ah [62]: 11:

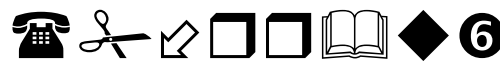

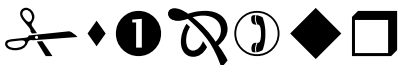

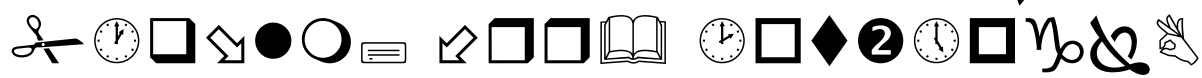

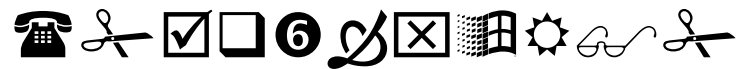

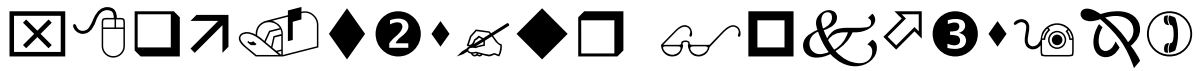

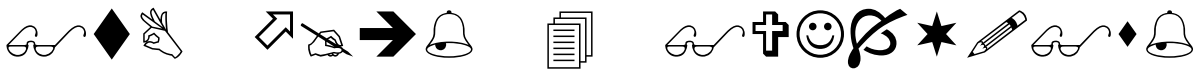

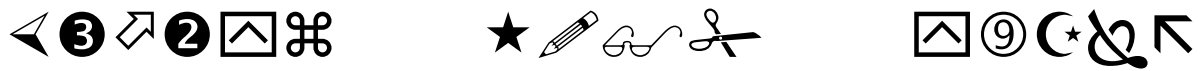

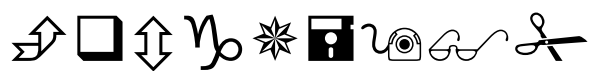
भ्षाل) है

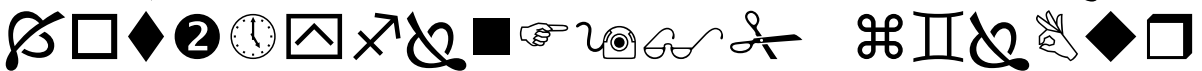

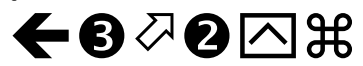
+ as 8

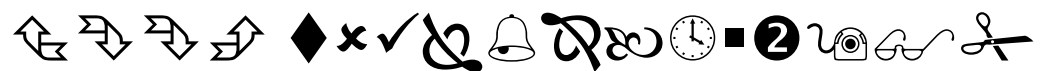
dan apabila mereka melihat perniagaan atau permainan, mereka bubar untuk menuju kepadanya dan mereka tinggalkan kamu sedang berdiri (berkhotbah). Katakanlah: "Apa yang di sisi Allah lebih baik daripada permainan dan perniagaan", dan Allah Sebaik-baik pemberi rezki. (Q.S al-Jumu'ah [62]: 11)

b. Ayat-ayat yang berkaitan dengan Bisnis (Tijarah) secara khusus

1) Q.S al-Baqarah [2]: 282:

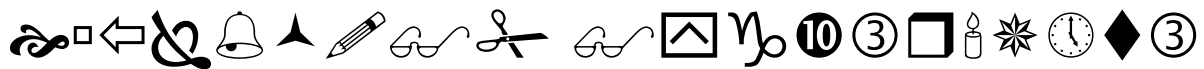
के 10 (र) क्षक्षण

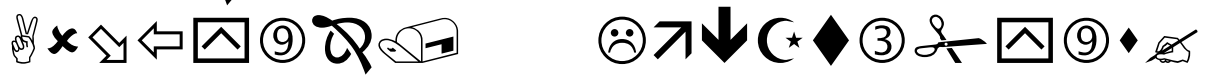
6-: O10 है 20त

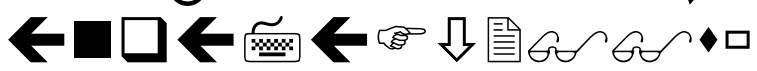

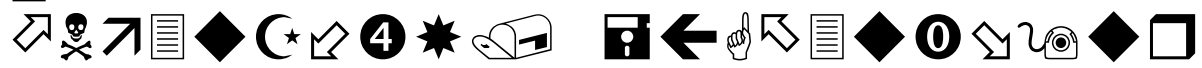

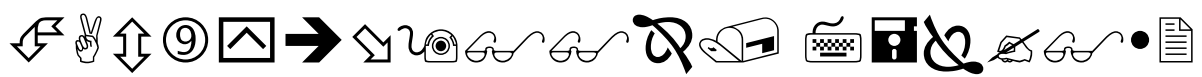
NFל

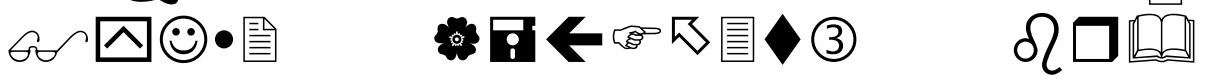
国 + G of

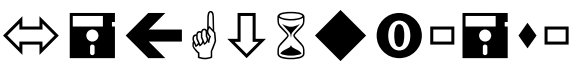

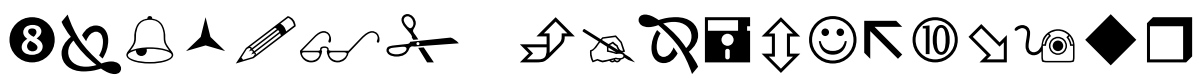

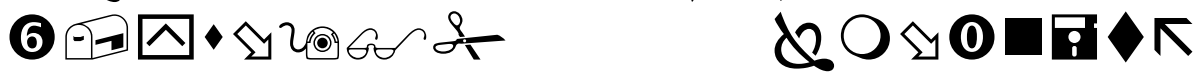

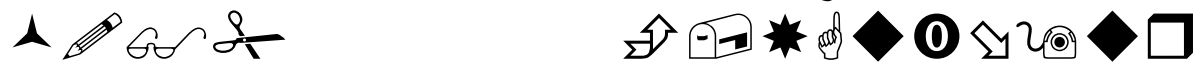

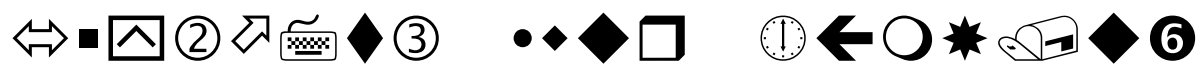

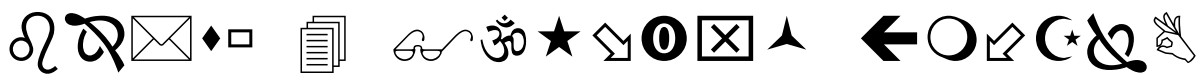


8de 1 ar of

$6 \oplus$ ब. 1206 of

$\checkmark \square \square \mathbb{Q D}$

-

$\checkmark \square \square \mathbb{E}$

$\checkmark \delta \odot 区$

d $\bigcirc \unlhd 0 \square \overline{7}$ र

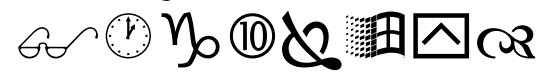

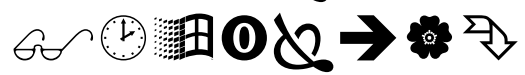
$\leftarrow \pi 0 \Leftrightarrow \partial \Leftrightarrow \Leftrightarrow O \square(4)$

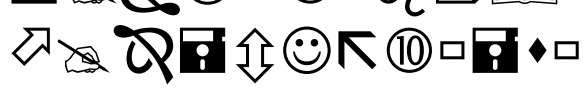

$\square \rightarrow \Omega$

(1) $600020 \square$

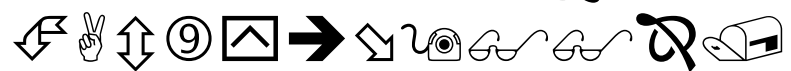
क्ष II है

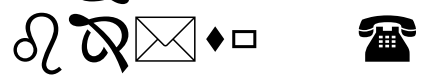

Go

$4 \times \zeta \vee 2$

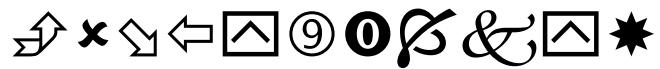

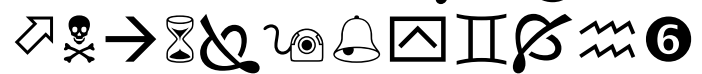
次人 20

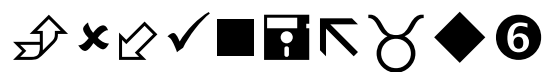

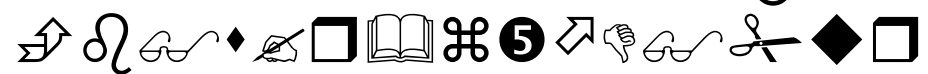

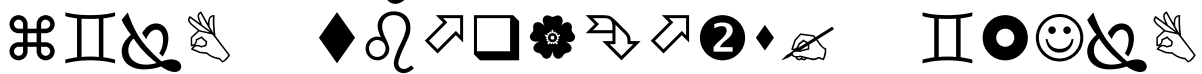
凤口四 இत \& G

$\checkmark 2$ 出算区 $0<6$

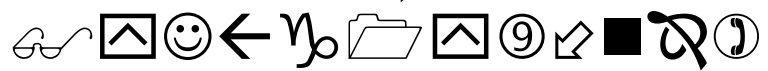

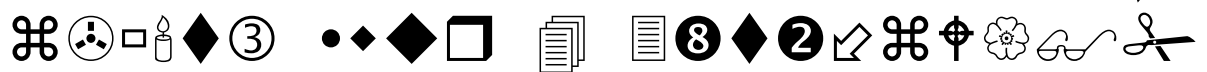
\& 10 (1) $\downarrow \pi$ \&

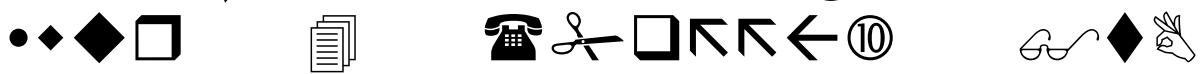

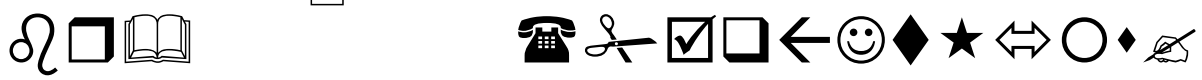

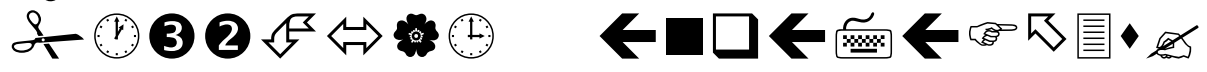

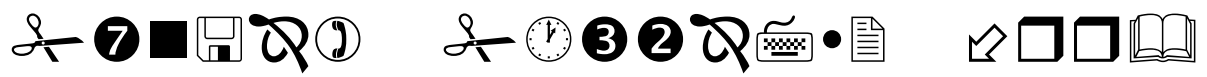
邓9

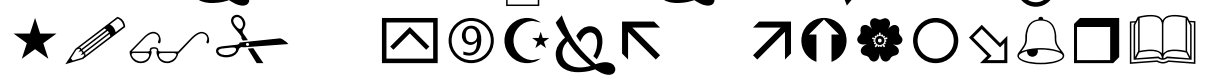

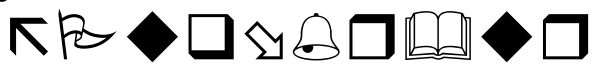

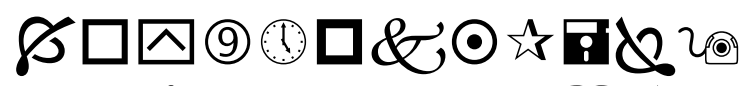

$\cdot \square \mathbb{\square}$

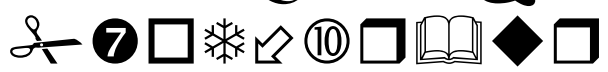

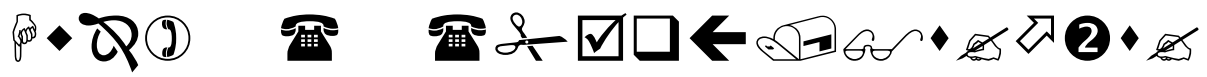

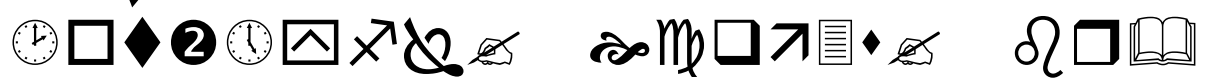




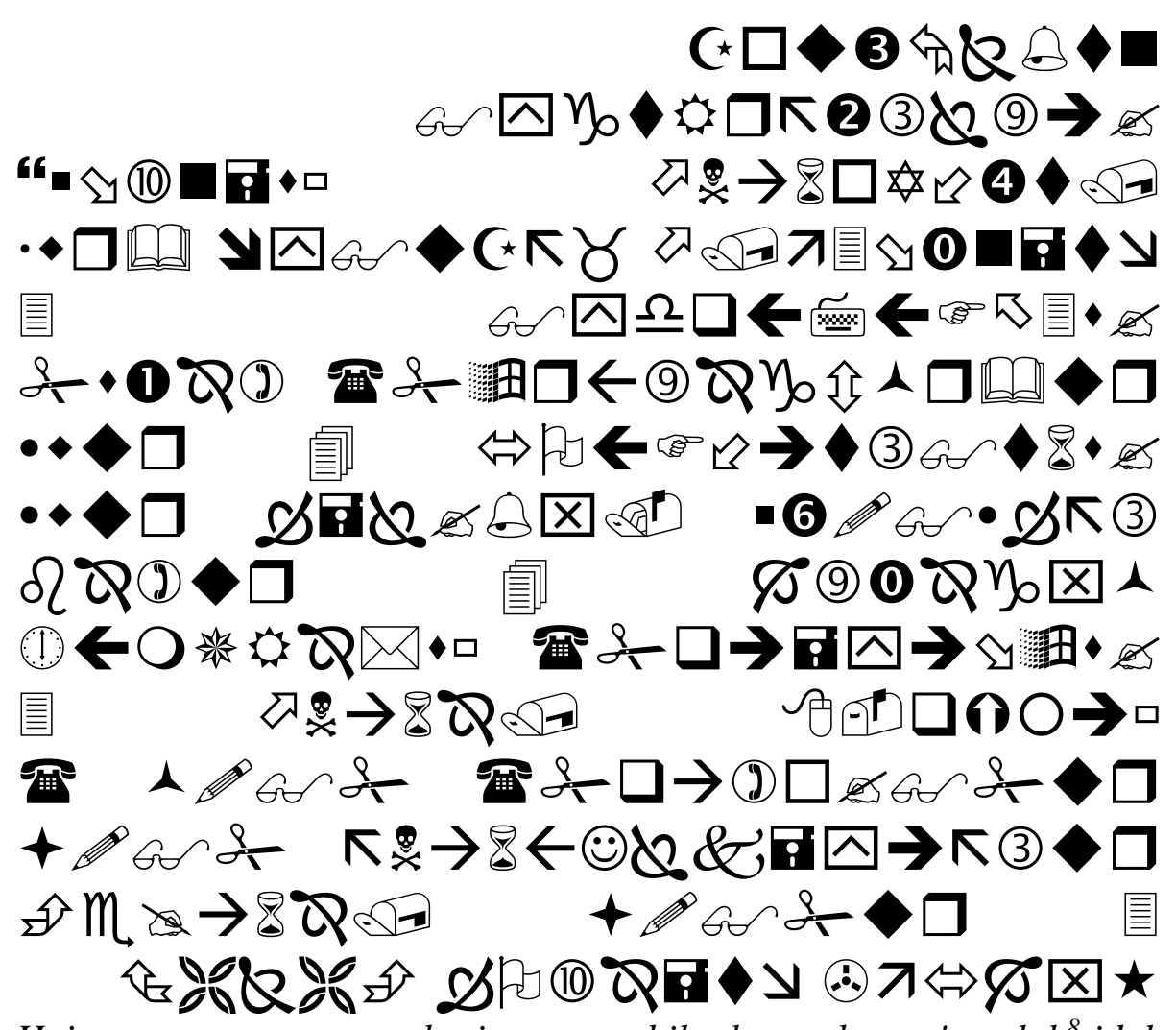

Hai orang-orang yang beriman, apabila kamu bermu'amalah ${ }^{8}$ tidak secara tunai untuk waktu yang ditentukan, hendaklah kamu menuliskannya. dan hendaklah seorang penulis di antara kamu menuliskannya dengan benar. dan janganlah penulis enggan menuliskannya sebagaimana Allah mengajarkannya, meka hendaklah ia menulis, dan hendaklah orang yang berhutang itu mengimlakkan (apa yang akan ditulis itu), dan hendaklah ia bertakwa kepada Allah Tuhannya, dan janganlah ia mengurangi sedikitpun daripada hutangnya. jika yang berhutang itu orang yang lemah akalnya atau lemah (keadaannya) atau Dia sendiri tidak mampu mengimlakkan, Maka hendaklah walinya mengimlakkan dengan jujur. dan persaksikanlah dengan dua orang saksi dari orang-orang lelaki (di antaramu). jika tak ada dua orang lelaki, Maka (boleh) seorang lelaki dan dua orang perempuan dari saksi-saksi yang kamu ridhai, supaya jika seorang lupa Maka yang seorang mengingatkannya. janganlah

8 Bermuamalah ialah seperti berjual beli, hutang piutang, atau sewa menyewa dan sebagainya. 
saksi-saksi itu enggan (memberi keterangan) apabila mereka dipanggil; dan janganlah kamu jemu menulis hutang itu, baik kecil maupun besar sampai batas waktu membayarnya. yang demikian itu, lebih adil di sisi Allah dan lebih menguatkan persaksian dan lebih dekat kepada tidak (menimbulkan) keraguanmu. (Tulislah mu'amalahmu itu), kecuali jika mu'amalah itu perdagangan tunai yang kamu jalankan di antara kamu, Maka tidak ada dosa bagi kamu, (jika) kamu tidak menulisnya. dan persaksikanlah apabila kamu berjual beli; dan janganlah penulis dan saksi saling sulit menyulitkan. jika kamu lakukan (yang demikian), Maka Sesungguhnya hal itu adalah suatu kefasikan pada dirimu. dan bertakwalah kepada Allah; Allah mengajarmu; dan Allah Maha mengetahui segala sesuatu. (Q.S alBaqarah [2]: 282)

2) Q.S. an-Nisa' [4]: 29

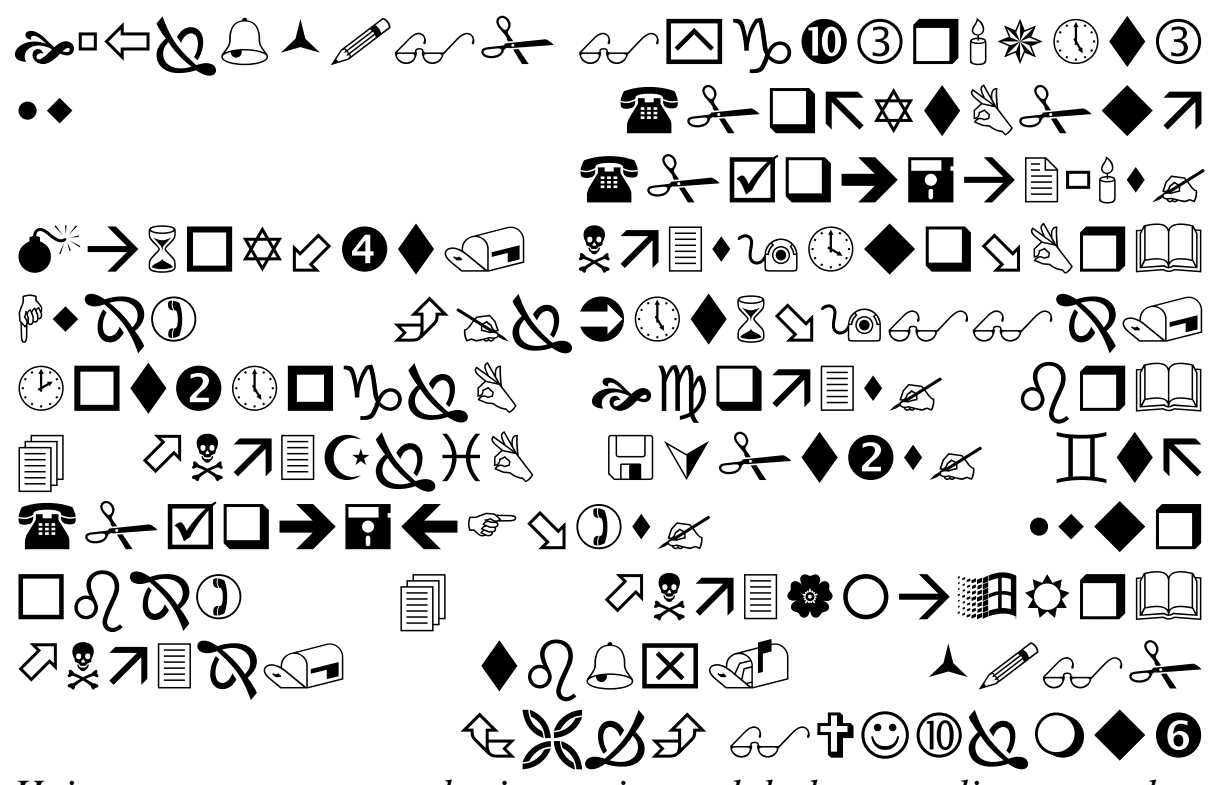

Hai orang-orang yang beriman, janganlah kamu saling memakan harta sesamamu dengan jalan yang batil, kecuali dengan jalan perniagaan yang Berlaku dengan suka sama-suka di antara kamu. dan janganlah kamu membunuh dirimu'; Sesungguhnya Allah adalah Maha Penyayang kepadamu. (Q.S an-Nisa' [4]: 29)

3) Q.S an-Nur [24]: 37

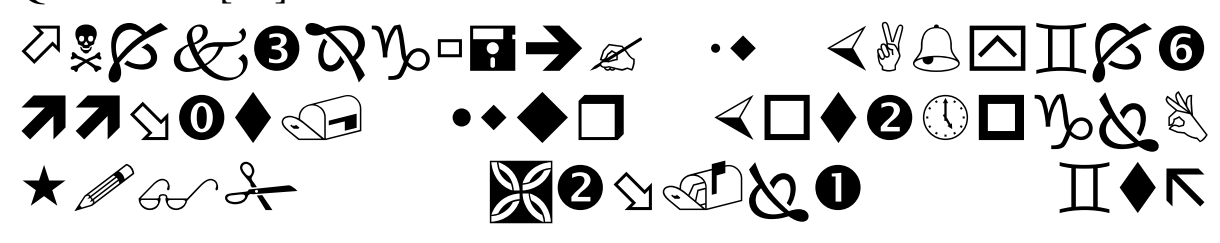

${ }^{9}$ Larangan membunuh diri sendiri mencakup juga larangan membunuh orang lain, sebab membunuh orang lain berarti membunuh diri sendiri, karena umat merupakan suatu kesatuan 

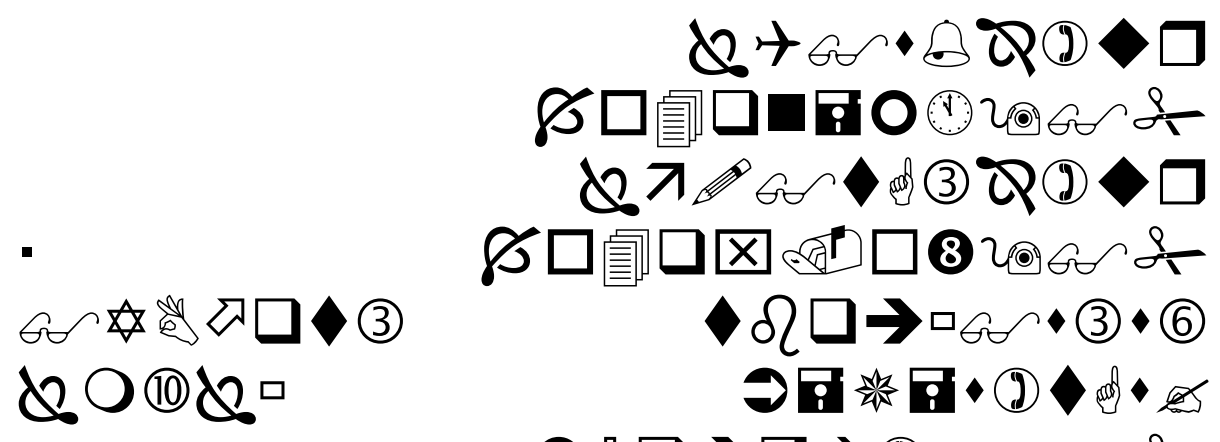

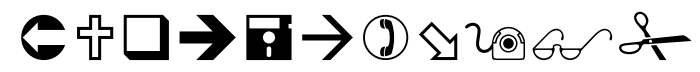

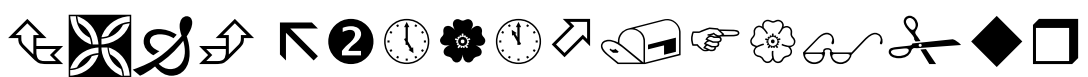

laki-laki yang tidak dilalaikan oleh perniagaan dan tidak (pula) oleh jual beli dari mengingati Allah, dan (dari) mendirikan sembahyang, dan (dari) membayarkan zakat. mereka takut kepada suatu hari yang (di hari itu) hati dan penglihatan menjadi goncang. (Q.S an-Nur [24]: $37)^{10}$

4. Konsep al-Hadist tentang Bisnis

Hadis yang diriwayatkan oleh imam Muslim, Turmudzi, Nasa'I, Abu Dawud dan Darimi disebutkan bahwa Nabi bersabda:

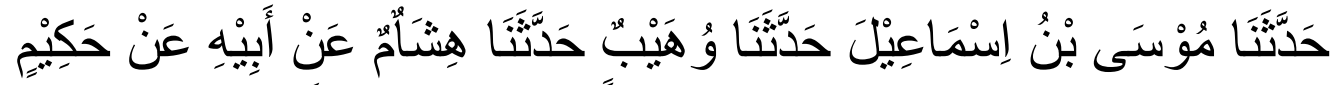

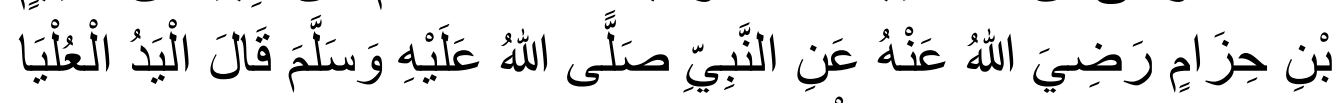

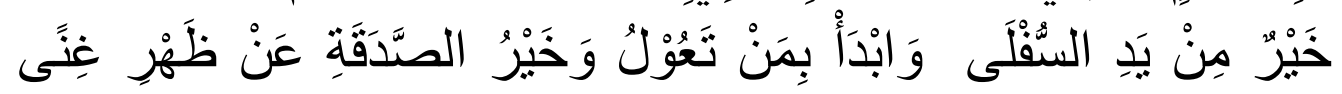

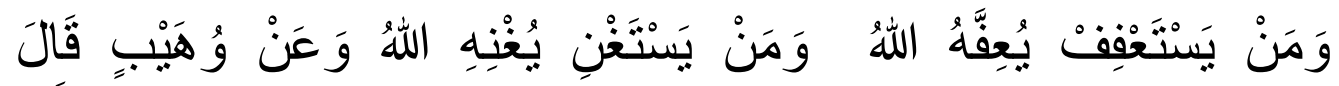

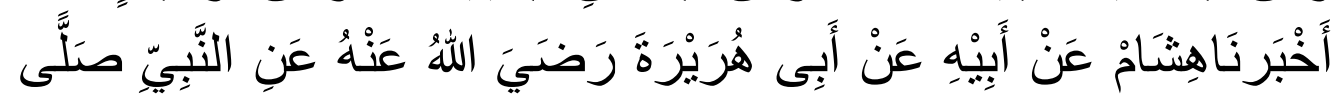

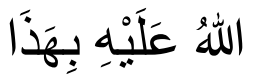

Nabi bersabda: "Tangan di atas lebih baik dari tangan dibawah, mulailah orang-orang yang wajib kamu nafkahi, sebaik-baiknya sedekah dari orang yang tidak mampu (dilluar kecukupan), barang siapa yang memelihara diri (tidak meminta-minta) maka Allah akan memeliharanya, barang siapa yang mencari kecukupan maka akan dicukupi oleh Allah."

(Matan lain: Muslim 1716, 1718, Turmudzi 2387, Nasa'I 2484, 2496, 2497, 2554, 2555, 2556, Abu Dawud 1427, Ahmad 6487, 7044, 7120, 7414, 8348, 8388, 8759, 8855, 9240, 9833, 10107, 10366, 10398, 14778, 14787, 15022, Darimi).

Maksud hadis tersebut tidak memperbolehkan meminta-minta, tetapi memotifasi agar seorang muslim mau berusaha dengan keras agar dapat

${ }^{10}$ Ika Yunia Fauuzia, Etika Bisnis dalam Islam (Jakarta: Kencana, 2013), Hlm. 7-11 
menjadi tangan di atas, yaitu orang-orang yang mampu membantu dan memberi sesuatu pada orang lain dari hasil jerih payahnya sendiri.

Islam mencela orang yang mampu untuk bekerja dan memiliki badan yang sehat tetapi tidak mau berusaha keras. Seoarang muslim harus dapat memanfaatkan karunia yang diberikan Allah yang berupa kekuatan dan kemampuan diri untuk bekal hidup layak di dunia akhirat. Etos kerja yang tinggi merupakan cerminan diri seorang muslim. ${ }^{11}$

Nabi Muhammad menyatakan bahwa usaha yang paling baik adalah berbuat sesuatu dengan tangannya sendiri dengan syarat jika dilakukan dengan baik dan jujur. Kalimat amalu ar-rijalu biyadihi dalam hadis tersebut di atas yang berarti usaha seseorang dengan tangannya dapat dimaknai dengan bisnis (wirausaha), karena dengan melakukan sesuatu dengan tangannya sendiri berarti seseorang dituntut dapat menciptakan sesuatu dan dapat memanfaatkan peluang dan kemampuan yang dimiliki. Sebagaimana Rasulullah bersabda: ${ }^{12}$

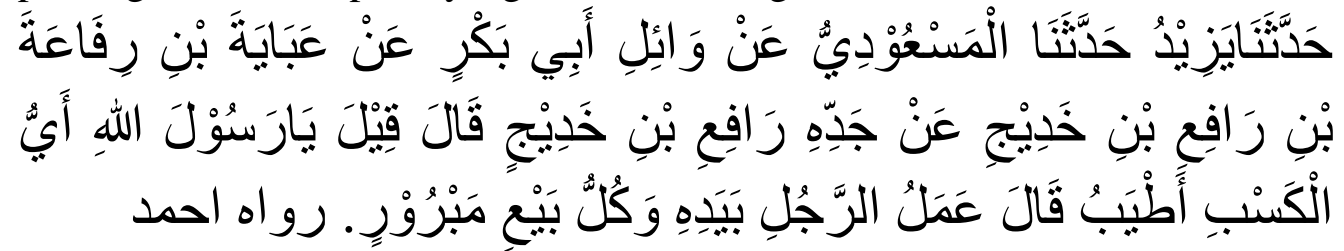

Rasulullah SAW. ditanya: "Usaha apa yang paling baik ?" Beliau menjawab: "Usaha seseorang dengan tangannya sendiri dan jual bali yang baik. (H.R. Ahmad)

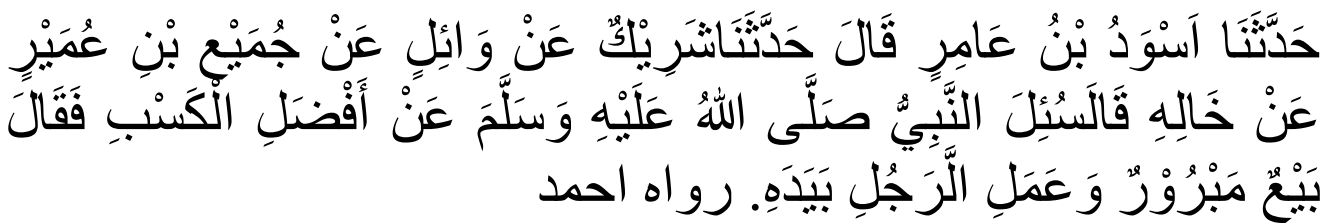

Nabi SAW. ditanya tentang usaha yang paling utama, beliau menjawab: "Jual beli yang baik dan dan usaha seseorang dengan tangannya sendiri." (H.R. Ahmad)

Hadis Ahmad yang pertama menyatakan: "Yang terbaik adalah usaha seseorang dengan tangannya dan jual beli, "sedang hadis kedua menyatakan bahwa: Yang paling utama adalah jual beli dan usaha seseorang dengan tangannya." Ini tidak berarti urutan pertama adalah usaha seseorang dengan tangannya, sedang urutan kedua adalah jual beli, atau sebaliknya, tetapi menunjukkan keduanya saling berkaitan agar dapat mencapai yang terbaik dalam melakukan usaha atau bisnis dibutuhkan keterampilan dan pikiran yang kreatif dan inovatif. ${ }^{13}$

${ }^{11}$ Lifi Nur Diana, Hadis-hadis Ekonomi (Malang: UIn Maliki Press, 2012),hlm. 201-202

${ }^{12}$ Abdul Aziz, Etika Bisnis Perspekitif Islan : Implementasi Etika Islam untuk Dunia Usaha. Hlm. 112

${ }^{13}$ Lifi Nur Diana, Hadis-hadis Ekonomi (Malang: UIN Maliki Press, 2012),hlm. 204-205 
5. Prinsip-Prinsip Bisnis Syariah (Islam)

a. Prinsip Umum Bisnis Syariah

Dalam Bisnis Syariah, terdapat beberapa prinsip dasar yang harus diperhatikan yaitu:

1) kaidah Fikih (Hukum Islam yang menyatakan), "pada dasarnya segala bentuk muamalah adalah boleh kecuali ada dalil yang mengharamkan"

2) muamalah dilakukan dengan atas dasar pertimbangan mendatangkan manfaat dan menghindarkan mudarat (jalbu al-mashalih wa dar'u al mafashid) atau sering disebut maslahah

3) Muamalah dilakukan dengan memelihara nilai keseimbangan (tawazun) dalam pembangunan

4) muamalah dilaksanakan dengan memelihara nilai keadilan dan menghindari dari unsur-unsur kezaliman. Segala bentuk muamalah yang mengandung unsur penindasan tidak dibenarkan.

Keadilan hanya menempatkan sesuatu pada tempatnya dan memberikan sesuatu hanya pada yang berhak, serta memperlakukan sesuatu sesuai posisinya.

b. Prinsip Khusus Bisnis Syariah (Islam)

Menurut Quraish Shihab dikutip oleh Mardani, prinsip bisnis syariah, dalam kontets ketentuan-ketentuan yang ditetapkan al-Qur'an dan konteks berbisnis paling tidak dikelompokkan dalam tiga kelompok:

a. Berkaitan dengan hati/kepercayaan pembisnis

1) Pembisnis perlu memiliki motivasi dan niat yang benar dalam konteks mencari dan menafkakan harta, agar bernilai ibadah.

2) Harta adalah milik dan Amanah Allah yang diserahkan kepada manusia agar mereka tunaikan sesuai pesan Allah.

3) Harta adalah ujian

4) Allah adalah penganugrah rezeki

5) Allah menjamin rezeki mahluknya

6) Rezeki bukan hanya besifat material, tetapi juga besifat imateri/spiritual

b. Berkaitan dengan Moral Pebisnis

1) kejujuran

Tentang kejujuran terdapat dalam Hadis Rasulullah Saw "Tidak dibenarkan seorang Muslim menjual satu jualan yang mempunyai aib kecuali ia menjelaskannya." (HR. al-Quzwain).

2) Pemenuhan janji dan perjanjian

Al-Qur'an dan sunah secara tegas telah memerintahkan untuk memenuhi segala macam janji dan ikatan perjanjian

3) Toleransi, keluwesan, dan keramahtamahan 
Nabi Muhammad Saw bersabda: "Allah merahmati seseorang yang ramah dan toleran dalam menjual, membeli, dan menagih" (HR. Bukhari dan Tirmidzi).

c. Berkaiatan dengan Pengembangan Harta

1) Prinsip halal (tidak dibenarkan memperdagangkan barang-barang yang diharamkan)

2) Saling menerima dengan baik (tidak dibernakan jual beli dengan paksaan)

3) Manfaat (tidak dibenarkan melakukan pergadangan yang tidak bermanfaat)

4) Keseimbangan (keuntungan antara pembeli dan penjual haruslah seimbang)

5) Kejelasan (maksudnya agar interaksi tidak berpotensi melahirkan perselisihan)

Menurut M. Azrul tanjung dikutip Mardani, Prinsip bisnis syariah sebagai berikut:

a. Halal

Halal dikatagorikan kepada dua bagian, yaitu:

1) Halal Dzatihi/Lidzatihi (Materiil)

Yaitu halal yang dinilai dari wujud kebenaran dari suatu barang. Untuk memenuhi syarat ini, maka materi/benda yang dipergunakan itu haruslah tidak termasuk jenis-jenis materi/benda yang diharamkan untuk dikonsumsi.

2) Halal Maknawi/Lighairi (Imateriil/Sebab lain)

Halal maknawi adalah kehalalan sebuah benda untuk diperdagangkan semata-mata didasarkan pada mekanisme dan cara-cara barang tersebut didapat. Meskipun suatu barang itu tidak haram secara materiel/benda, namun bisa jadi benda tersebut haram, karena barang tersebut diperoleh dengan cara yang dilarang oleh hukum Islam.

3) Thayyiban.

Selain mewajibkan bisnis yang halal, Islam juga mengutamakan bisnis yang Thayyiban yaitu sesuatu yang baik dan memberikan manfaat tidak hanya bagi diri sendiri tetapi juga mitra bisnis dan masyarakat luas.

4) Kejujuran

Agar tidak merugikan mitra bisnis traksaksi atau pelanggan, maka bisnis menurut Islam mengutamakan kejujuran.

5) Kewajaran 
Bisnis harus dijalankan secara wajar (fair). Salah satu bentuk kewajaran dalam bisnis adalah dalam mengambil keuntungan.

6) Seimbang

Berbisnis menurut ajaran Islam haruslah dilakukan untuk menjaga keseimbangan dan keselarasan dengan alam raya serta kemakmuran bumi.

7) Etos kerja

Islam adalah agama amal (kerja), baik untuk kepentingan hidup di dunia maupun kehidupan setelah mati di akhirat. ${ }^{14}$

6. Prinsip-Prinsip Etika Bisnis Islamri

Untuk membangun kultur bisnis yang sehat, idealnya dimulai dari perumusan etika yang digunakan sebagai norma perilaku sebelum atutan (hukum). Aturan etika tersebut di wujudakan dalam bentuk aturan hukum.

Karena itu, etika bisnis secara umum, menurut Suarny Arman dikutip Abdul Aziz, harus berdasarkan prinsip-prinsip sebagai berkut:

a. Prinsip Otonomi

Yaitu kemampuan untuk mengambil keputusan dan bertindak berdasarkan keselarasan tentang apa yang baik untuk dilakukan dan bertanggung jawab atas keputusan yang diambil

\section{b. Prinsip Kejujuran}

Kejujuran adalah merupakan kunci keberhasilan suatu bisnis, kejujuran dalam pelaksanaan kontrol terhadap konsumen, hubungan kerja dan sebagainya

c. Prinsip keadilan

Setiap seseorang dalam berbisnis diperlakukan sesuai dengan haknya masing-masing dan tidak boleh ada yang dirugikan

d. Prinsip Saling menguntungkan

e. Prinsip integritas moral

Yaitu merupakan dasar dalam berbisnis, harus menjaga nama baik perusahaan tetap percaya dan merupakan perusahaan terbaik.

Demikian pula dalam Islam, etika bisnis Islam harus berdasarkan pada prinsip-prinsip dasar yang berlandasan pada al-Qur'an dan al-Hadis, sehingga dapat diukur dengan aspek dasarnya yang meliputi:

a. Barometer Ketaqwaan Seseorang. Allah berfirman dalam Q.S. alBaqarah[2]: 188.

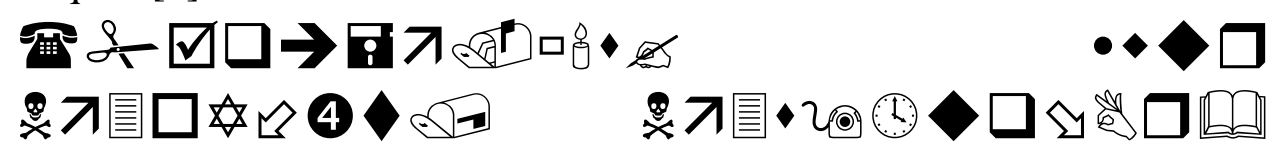

${ }^{14}$ Mardani, Hukum Bisnis Syariah (Jakarta: Prenadamedia Group, 2014), hal. 31-38 


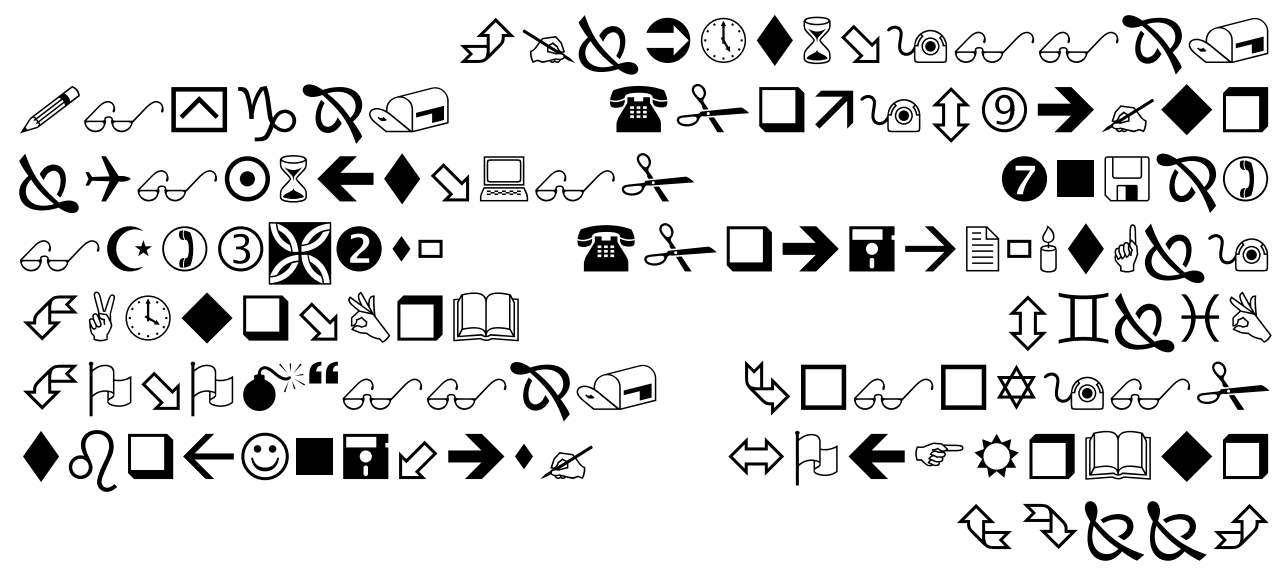

Dan janganlah sebahagian kamu memakan harta sebahagian yang lain di antara kamu dengan jalan yang bathil dan (janganlah) kamu membawa (urusan) harta itu kepada hakim, supaya kamu dapat memakan sebahagian daripada harta benda orang lain itu dengan (jalan berbuat) dosa, Padahal kamu mengetahui. (Q.S al-Baqarah[2]: 188)

Ayat ini berada persis setelah ayat-ayat yang berkiatan dengan ibdah Ramadhan (Q.S. [2]: 183, 184, 186, dan 189), di mana output dari Ramadhan adalah TAQWA. Sehinga ayat ini menunjukkan bahwa salah satu cirri mendasar orang yang taqwa adalah senantiasa bermualah dengan Mu'amalah Islami (ber-bisnis secara Islami).

b. Mendatangkan keberkahan. Allah SWT. berfirman dalam Q.S. Al-A'raf [7]: 96

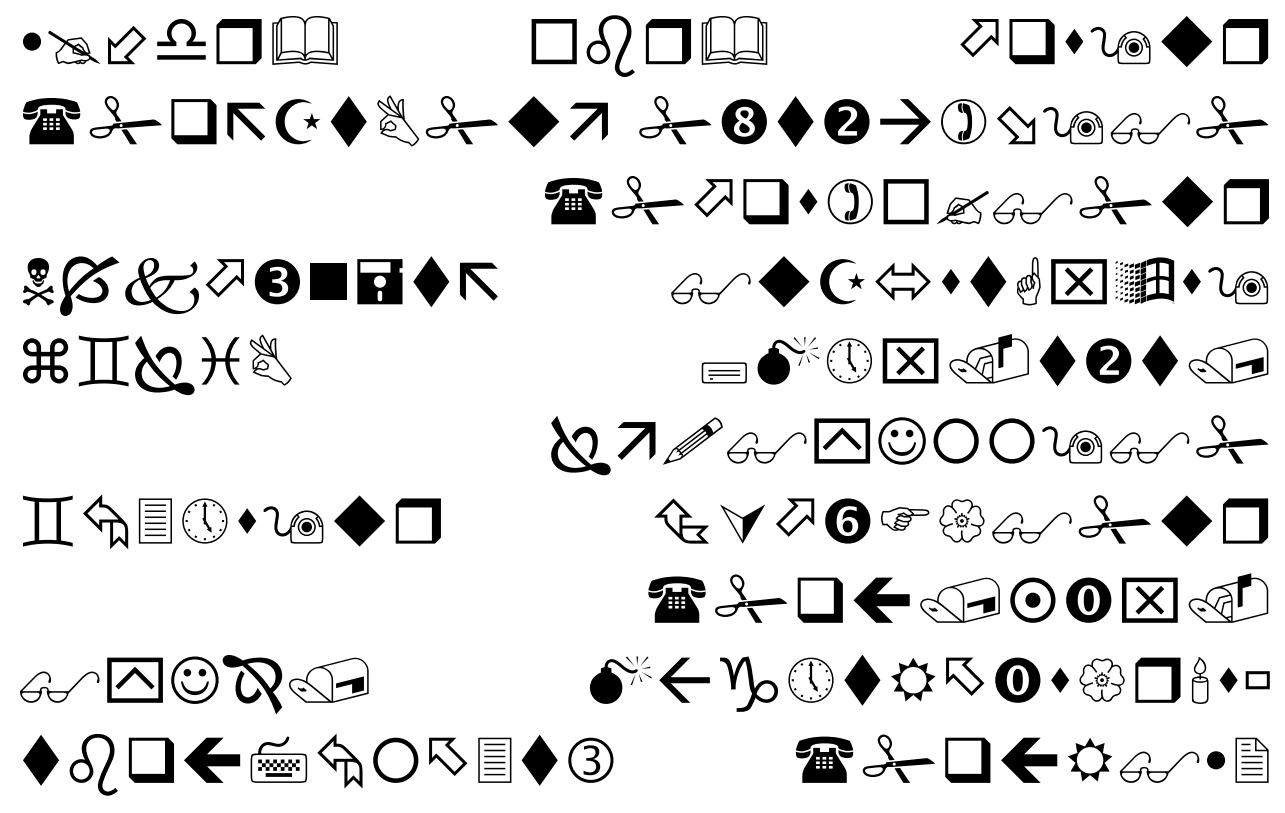

B. 5820

Jikalau Sekiranya penduduk negeri-negeri beriman dan bertakwa, pastilah Kami akan melimpahkan kepada mereka berkah dari langit dan bumi, 
tetapi mereka mendustakan (ayat-ayat Kami) itu, Maka Kami siksa mereka disebabkan perbuatannya. (Q.S al-A'raf[7]: 96)

Harta yang diperoleh dengan cara yang halal dan baik akan mendatangkan keberkahan pada harta tersebut, sehingga pemanfaatan harta dapat lebih maksimal bagi dirinya maupun bagin orang lain.

c. Mendapatkan derajat Seperti Para Nabi, Shiddiqin \& Shuhada Rasulullah SAW. bersabda:

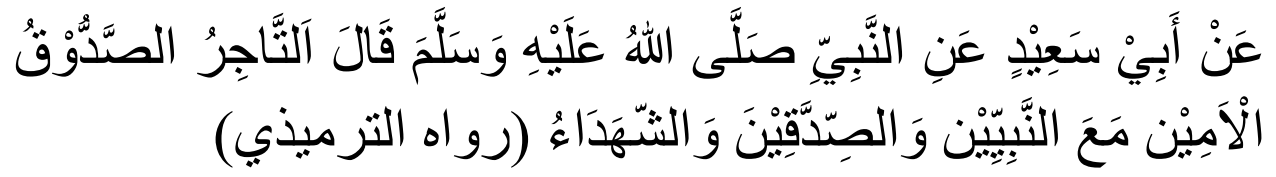

Artinya

"Dari Abu Sa'id al-Hudri ra beliau berkata bahwa Rasululah SAW. bersabda, Pebisnis yang jujur dan dipercaya (amanah) akan bersama para nabi, shiddiqin dan syuhada'". (H.R. Turmdzi)

d. Berbisis merupakan sarana Ibadah Kepada Allah SWT. Banyak ayat yang menggarbarkan bahwa aktivitas bisnis merupakan sarana ibadah.

Ada enam langkah awal dalam memulai etika bisnis Islam, yaitu:

a. Niat Ikhlas Mengharap Ridha Allah SWT. Rasulullah SAW. bersabda:

"Bahwasanya segala amal perbuatan manusia itu tergantunng dari niatnya. Dan bahwasanya bagi setiap orang (akan mendapatkan) dari apa yang telah diniatkannya. Barang siapa yang hijrahnya dunia, atau karena wanita yang ingin dinikahinya, maka hijrahnya itu hanya akan mendapatkan apa yang telah diniatkannya." (H.R. Bukhari)

b. Profesional (الاتقان فى العمل). Rasulullah bersabda:

"Dari Aisyah ra. Rasulullah SAW. bersabda, Sesungguhnya Allah mencintai seseorang yang apabila dia beramal, dia menyempurnakan amalnya." (H.R. Thabrani)

c. Jujur \& Amanah (الصدق والامنة) Rasulullah SAW bersabda:

"Dari Abu Sa'id Al-Khudri ra beliau berkata bahwa Rasulullah Bersabda,"Pebisnis yang jujur lagi dipercaya (amanah) akan bersama para Nabi, shiddiqin dan syuhada." (HR.Turmudzi)

d. Mengedepankan Etika Seorang Muslim Rasulullah bersabda:

"Dari Abu Hurairah ra. Rasulullah Saw. bersabda, Orang beriman yang paling sempurna keimanannya adalah yang paling baik akhlaknya. Dan sebaik-baiknya kalian adalah yang paling baik akhlaknya terhadap istriistrinya." (H.R. Turmudzi)

e. Tidak Melanggar Prinsip Syariah.

f. Ukhuwah Islamiyah Rasulullah bersabda: 
"Sesungguhnya diantara hamba-hamba Allah ada sekelompok manusia yang mereka itu bukan para nabi dan bukan pula orang-orang yang mati syahid, namun posisi mereka pada hari kiamat mambuat membuat nabi dan syuhada' menjadi iri. Sahabat bertanya, 'Beritahukan kepada kami, siapa mereka itu? Rasulullah Saw. menjawab, 'mereka adalah satu kaum yang saling mencintai kerena Allah meskipun di antara mereka tidak ada hubungan kekerabatan dan tidak pula ada motivasi duniawi. Demi Allah wajah mereka bercahaya dan mereka berada di atas cahaya. Mereka tidak takut tatkala manusia takut, dan mereka tidak bersedih hati." (H.R. Abu Daud $)^{15}$

7. Implikasi Taqwa dalam Bisnis

Tampak dengan jelas bahwa taqwa berkaitan dengan perilaku dan sikap mental, atau dengan ungkapan lain taqwa merupakan sintesa kedua unsur itu. Seorang yang muttaqin ialah orang yang mempunyai perilaku yang baik dan sikap mental atau integritas yang mantap dan konsekwensi dalam melaksanakan perintah dan meninggalkan larangan Allah SWT.

Dengan dimilikinya sifat taqwa yang demikian kuat, maka seorang pebisnis akan melakukan usaha-usaha bisnis dengan cara-cara yang halal serta jauh dari praktek-praktek ekspoitasi, monopoli dan semua unsur yang akan mengakibatkan kerugian pihak lain.

Dengan adanya sifat taqwa, seorang pebisnis tidak perlu mengindari persaingan selama dilakukan secara santun dan penuh keakraban; dalam arti persaingan itu tidak dalam konteks saling menjatuhkan melainkan sama-sama berusaha mendapatkan keuntungan dengan cara yang benar.

Begitulah efektifnya sifat taqwa dalam menjaga dan mengayomi kehidupan umat, jangankan melakukan riba, menumpuk barang saja dia tidak mau; tapi sebaliknya jika taqwa tidak dimiliki oleh seorang pebisnis maka kemungkinan dia menempuh cara-cara yang tidak benar atau haram sangat besar dilakukan sekalipun dia mengaku beriman, namun kalau taqwa tidak ada atau tipis, masih mudah tergoda oleh berbagai rayuan duniawi yang kadangkadang lahiriyahnya ukhrawi, tapi bathiniyahnya duniawi. Untuk mengimplementasikan etika islam dalam berbisnis itu tidak ada jalan lain kecuali lewat jalur taqwa, yakni dia merasakan ada hubungan batin yang terus menerus antara dia dengan Allah SWT. seperti yang dimiliki oleh seorang yang tulus (mukhlis) dalam beramal. Jika kondisi kejiwaan yang demikian telah tertanam di dalam dirnya, maka, bisnis yang dilakukannya tidak mungkin

\footnotetext{
${ }^{15}$ Abdul Aziz, Etika Bisnis Perspekitif Islan : Implementasi Etika Islam untuk Dunia Usaha.
} Hlm 36-41 
membuat orang lain terdzalimi dan dia pun akan mendapatkan keuntungan ganda, di dunia dan akhirat. ${ }^{16}$

\section{Penutup}

Bisnis dan etika tidak harus dipandang sebagai dua hal yang bertentangan, karna, bisnis merupakan simbol dari urusan duniawi juga dianggap sebagai integral dari hal yang bersifat investasi akhirat. maka bisnis dengan sendirinya harus sejalan dengan kaidah-kiadah moral yang berlandasan keimanan kepada akhirat.

Untuk membangun kultur yang sehat dalam bisnis maka dalam etika bisnis Islam terdapat beberapa prinsip diantaranya adalah tentang Barometer Ketaqwaan Seseorang dan Berbisnis merupakan sebagai sarana untuk beribadah kepada Allah SWT. Untuk memulai etika bisnis Islam terdapat enam hal yang harus dilakukan, yaitu: Niat Ikhlas Mengharap Ridha Allah SWT. Profesional (الاتقان فى العمل). Jujur \& Amanah (الصدق والامنة). Mengedepankan Etika Seorang Muslim. Tidak Melanggar Prinsip Syariah. Dan yang terahir Ukhuwah Islamiyah.

Namun semua itu tidak bisa di lakukan tampa disertai dengan taqwa kapada Allah. Dengan dimilikinya sifat taqwa yang demikian kuat, maka seorang pebisnis akan melakukan usaha-usaha bisnis dengan cara-cara yang halal serta jauh dari praktek-praktek ekspoitasi, monopoli dan semua unsur yang akan mengakibatkan kerugian pihak lain.

${ }^{16}$ Nashruddin \& Erwati Aziz, Etika Islam dalam Berbisnsi (Solo: Zada Haniya, 2008), Hlm. 


\section{Daftar Pustaka}

Aziz, Abdul, 2013. Etika Bisnis Perspekitif Islan : Implementasi Etika Islam untuk Dunia Usaha (Bandung: AL-Fabeta)

Alwa, Buchari \& Juni, Doni Priansa, 2016. Manejemen Bisnis Syariah (Bandung: Alfabeta)

Badroen, Faisal, et al, 2012. Etika Bisnis Dalam Islam (Jakarta: Prenadamedia Group) Yunia, Ika, Fauuzia, 2013. Etika Bisnis dalam Islam (Jakarta: Kencana)

Nur, Lifi, Diana, 2012. Hadis-hadis Ekonomi (Malang: UIN Maliki Press)

Mardani, 2014. Hukum Bisnis Syariah (Jakarta: Prenadamedia Group)

Nashruddin, \& Aziz, Erwati, 2008. Etika Islam dalam Berbisnis (Solo: Zada Haniya) 